\title{
Respons Pertumbuhan Tanaman Kacang Hijau (Vigna radiata) terhadap Pemberian Pupuk Organik Cair Limbah Air Kelapa dan Keong Mas
}

\author{
Elis Hidayanti $^{{ }^{*}}$, Emilda $^{1}$, Titin Supriyatin ${ }^{1}$ \\ ${ }^{1}$ Fakultas MIPA, Prodi Pendidikan Biologi, Universitas Indraprasta PGRI \\ *email: hanyuki1004@gmail.com
}

Article History
Received:
18/07/2021
Revised:
31/08/2021
Accepted:
11/09/2021

Kata kunci:

Air kelapa

Keong mas

Kacang hijau

(Vigna radiata)

Pupuk cair

Key word:

Coconut water

Golden snail

Liquid fertilizer

Mung bean

(Vigna radiata)

\begin{abstract}
ABSTRAK
Penelitian ini bertujuan untuk mengetahui respons pertumbuhan tanaman kacang hijau (Vigna radiata) terhadap pemberian pupuk organik cair (POC) limbah air kelapa dan keong mas. Parameter yang diamati terdiri atas tinggi tanaman, jumlah polong, bobot kering biji per tanaman, dan bobot kering akar. Metode yang digunakan yaitu eksperimen menggunakan Rancangan Acak Kelompok (RAK) dengan dua faktor, yakni perlakuan pada benih (T) dengan dua taraf yakni perendaman benih dengan aquadest (T1) dan dengan POC (T2), serta pemupukan dengan empat taraf POC, yaitu 0\% (P0), 15\% (P1), 30\% (P2), dan 45\% (P3). Adapun label kombinasi perlakuan dalam penelitian ini adalah T1P0, T1P1, T1P2, T1P3, T2P0, T2P1, T2P2, dan T2P3. Percobaan ini terdiri dari enam kali ulangan. Sehingga, terdapat 48 unit percobaan. Analisis data dilakukan menggunakan uji ANOVA 2 arah dan uji lanjutan DMRT 5\%. Hasil penelitian menunjukkan bahwa pemberian POC air kelapa dan keong mas memberikan respons positif terhadap peningkatan pertumbuhan tanaman kacang hijau. Kedua faktor perlakuan secara terpisah diketahui memberikan pengaruh sangat nyata ( $\mathrm{F}$ hitung $>\mathrm{F}$ tabel 1\%) pada seluruh indikator antara 17-67 hari setelah tanam (HST), kecuali faktor T yang memberikan pengaruh nyata pada tinggi 17 HST. Akan tetapi, kombinasi kedua faktor hanya memberikan pengaruh sangat nyata pada tinggi 27 HST dan nyata pada bobot kering biji per tanaman, namun tidak nyata pada indikator lainnya. Hasil uji lanjut menunjukkan bahwa pemupukan dengan 30\% POC memberikan pengaruh paling signifikan. Secara spesifik, diketahui bahwa kelompok T2P2 menyebabkan hasil pertumbuhan paling baik dengan rerata tinggi $80.08 \mathrm{~cm}$, jumlah polong 48.67 buah, bobot kering biji per tanaman $55.65 \mathrm{~g}$, dan bobot kering akar $7.2 \mathrm{~g}$.
\end{abstract}

ABSTRACT
This study aims to determine the growth response of mung bean (Vigna radiata) to implementation
of liquid organic fertilizer (LOF) based on coconut water and golden snail. Parameters observed
were the height of the plant, the number of pods, dry weight of seeds each plant, and dry weight of
root. The method used was experiment using Randomized Group Design with 2 factors. First factor
was seed treatment (T) with two levels, consists of invigoration using aquadest (T1) and using
LOF (T2), while the second factor was fertilizing using LOF with four concentration levels,
consists of $0 \%(P 0), 15 \%(P 1), 30 \%(P 2)$, and $45 \%(P 3)$. Combination symbol of treatment were
T1P0, TIP1, T1P2, T1P3, T2P0, T2P1, T2P2, and T2P3. Each treatment was repeated six times.
Therefore, this study used 48 unit plants. Data analyzed using two-way ANOVA and DMRT $5 \%$.
The results showed that administration of LOF based on coconut water and golden snail gives
positive response towards the increase growth of mung bean (Vigna radiata). Both factors
separately gave very significant effect on all parameters on $17-67$ days after planting (DAP),
except factor T which only gave significant effect on height of plant on 17 DAP. Unfortunately,
combination of both factors only gave very significant effect on height of plant on 27 DAP and
significant on dry weight of seeds, but non significant for other parameters. The further study
showed that fertilizing using $30 \%$ LOF gave the best result. Specifically, the result showed that
T2P2 gave the best growth of all, with average height 80,08 cm, number of pods 48.67 units, dry
weight of seeds each plant 55.65 g, and dry weight of root 7.2 g.

Copyright @ 2022 LPPM Universitas Indraprasta PGRI. All Right Reserved 


\section{PENDAHULUAN}

Tanaman kacang hijau adalah salah satu komoditas yang banyak dikonsumsi oleh masyarakat di Indonesia. Saat ini, terjadi peningkatan kebutuhan tanaman kacang hijau yang berbanding lurus dengan pertambahan jumlah penduduk dan berkembangnya industri pangan di Indonesia (Prayitna, 2017). Akan tetapi, jumlah ketersediaan kacang hijau belum memenuhi kebutuhan konsumsi masyarakat, sebagaimana ditunjukkan oleh angka ketersediaan per kapita yang menurun dari 1.12 pada tahun 2017 menjadi 1.05 di tahun 2018 (Komalasari, 2018). Hal ini relevan dengan Direktorat Jenderal Tanaman Pangan (2020) yang melaporkan bahwa pertumbuhan capaian produksi tahun 2019 lebih rendah dibandingkan dengan tahun 2018 pada indikator luas panen dan produksi, yakni sebesar $5.47 \%$. Kondisi tersebut berhubungan dengan budidaya tanaman yang kurang intensif serta terjadinya penurunan produktivitas lahan yang mempengaruhi produktivitas tanaman ini.

Pertumbuhan tanaman kacang hijau dipengaruhi oleh faktor internal tanaman, yaitu fitohormon (Sun et al., 2014) dan genetik (Jiao et al., 2019), serta faktor eksternal, yang berupa air, suhu, kelembaban, cahaya, tanah, dan pemenuhan zat hara (Azhari et al., 2018). Hara makro yang dibutuhkan oleh tanaman ini diantaranya adalah $\mathrm{C}$, $\mathrm{O}, \mathrm{N}, \mathrm{P}, \mathrm{S}, \mathrm{K}, \mathrm{Ca}$, dan Mg. Seperti tanaman lain pada umumnya, tanaman kacang hijau menyerap nutrisi yang berasal dari atmosfer, tanah, melalui daun dan akar.

Penurunan produktivitas lahan terjadi akibat adanya ketidakseimbangan komposisi mineral di dalam tanah. Pemupukan merupakan salah satu langkah untuk mengatasi kondisi tersebut. Pupuk yang akan digunakan dalam penelitian ini adalah pupuk organik cair. Pupuk organik cair merupakan pupuk alternatif yang berasal dari hasil perombakan bahan-bahan organik dengan bantuan mikroorganisme (Gitadevarsa et al., 2019). Secara spesifik, Hartatik et al. (2015) merinci peranan pupuk organik cair, yakni 1) sebagai penyedia hara makro dan mikro, 2) meningkatkan Kapasitas Tukar Kation (KTK) tanah, serta 3) membentuk senyawa kompleks dengan ion logam beracun seperti, Al, Fe, dan Mn, sehingga logam tersebut tidak meracuni. Salah satu bahan yang berpotensi digunakan sebagai pupuk organik cair adalah air kelapa (Prades et al., 2012).

Air kelapa diketahui mengandung ion anorganik $(\mathrm{Cl}, \mathrm{Cu}, \mathrm{Fe}, \mathrm{Mg}, \mathrm{P}, \mathrm{K}, \mathrm{Na}, \mathrm{S})$, senyawa nitrogen, asam amino, vitamin, enzim, dan asam organik yang dapat menginduksi pembelahan sel dan multiplikasi tunas (Harahap, 2014). Selain itu, air kelapa dilaporkan mengandung zat pengatur tumbuh alami berupa sitokinin (Manurung et al., 2017), auksin dan giberelin (Prianti et al., 2017). Zat pengatur tumbuh berperan penting dalam mendukung berbagai proses di dalam tubuh tanaman, sehingga dapat memberikan umpan balik positif bagi pertumbuhan tanaman.

Bahan lain yang dapat dimanfaatkan sebagai bahan pupuk organik cair adalah keong mas. Keong mas adalah herbivora polifag yang rakus (Liunokas et al., 2019) dan cepat berkembang biak (Dharmawati et al., 2016), serta umum dikenal sebagai organisme pengganggu tanaman (OPT) padi sawah (Suriyadi, 2020). Akan tetapi, meskipun keong mas merupakan hama bagi tanaman budidaya, namun hewan ini memiliki fungsi positif dalam ekosistem, karena dapat menjaga ekosistem tanah (Taufikurohman, 2018), sebagai bioindikator logam (Riyanto et al., 2015), bahan makanan manusia maupun ternak (Saputra $e t$ al., 2018; Putri et al., 2019), atau diolah menjadi ZPT organik (Suarmustika et al., 2018). Hal ini berkaitan dengan kandungan gizi yang terdapat dalam cangkang, daging, dan telur keong mas. Pambudi (2011) melaporkan bahwa nutrisi keong mas cukup tinggi, dengan nilai $\mathrm{Ca}$ dan $\mathrm{P}$ yang paling signifikan dibandingkan zat lainnya, yakni $7593.83 \mathrm{mg}$ dan $1454.32 \mathrm{mg}$ dalam $100 \mathrm{~g}$.

Pupuk organik cair limbah air kelapa dan keong mas mengandung unsur hara dan mikroba yang dapat merombak bahan organik, merangsang pertumbuhan, dan menjadi agen pengendali hama (Suhastyo et al., 2013). Perpaduan kedua bahan tersebut dapat memberikan pasokan nutrisi bagi tanaman, serta berpotensi untuk mereduksi populasi hama keong mas yang menjadi masalah bagi pertanian di Indonesia.

Berdasarkan pemaparan tersebut, maka tujuan dari penelitian ini adalah untuk mengetahui respons pertumbuhan tanaman kacang hijau (Vigna radiata) terhadap pemberian pupuk organik cair limbah air kelapa dan keong mas.

\section{METODE PENELITIAN}

Penelitian ini dilaksanakan pada bulan Februari sampai Juli 2021. Bahan yang digunakan meliputi benih kacang hijau merk panah merah, arang sekam, air kelapa, keong mas, air cucian beras, gula merah, dan aquadest. Adapun alat yang digunakan adalah ember berpenutup, alu, polybag berdiameter 
15 x $30 \mathrm{~cm}$, semprotan, gelas ukur, alat tulis, pita ukur, dan kamera.

Peneliti menggunakan metode penelitian kuantitatif. Rancangan percobaan yang digunakan adalah Rancangan Acak Kelompok (RAK) pola faktorial dengan dua faktor, yaitu perlakuan pada benih dan perbedaan konsentrasi pupuk organik cair. Setiap kelompok terdiri atas empat tanaman. Percobaan ini terdiri dari enam kali ulangan, sehingga terdapat 48 unit percobaan. Faktor dalam penelitian ini adalah sebagai berikut:

1) Perlakuan pada benih (T) dengan 2 taraf, yakni: $\mathrm{T}_{1}=$ Perendaman benih tanpa POC

$\mathrm{T}_{2}=$ Perendaman benih dengan POC

2) Perbedaan konsentrasi POC yang terdiri atas 4 taraf, sebagai berikut:

$\mathrm{P}_{0}=\mathrm{POC} 0 \%(0 \mathrm{~mL} \mathrm{POC}+100 \mathrm{~mL}$ air $)$

$\mathrm{P}_{1}=\mathrm{POC} 15 \%(15 \mathrm{~mL} \mathrm{POC}+85 \mathrm{~mL}$ air $)$

$\mathrm{P}_{2}=\mathrm{POC} 30 \%(30 \mathrm{~mL} \mathrm{POC}+70 \mathrm{~mL}$ air $)$

$\mathrm{P}_{3}=\mathrm{POC} 45 \%(45 \mathrm{~mL} \mathrm{POC}+55 \mathrm{~mL}$ air $)$

\section{Pembuatan Pupuk Organik Cair}

Pupuk organik cair (POC) dibuat sesuai anjuran Balai Pengkajian dan Teknologi Pertanian (BPTP) (2011), yakni dengan cara mencampurkan $2000 \mathrm{~g}$ keong mas yang sudah ditumbuk, $5000 \mathrm{~mL}$ air kelapa, $1000 \mathrm{~mL}$ air cucian beras, dan $100 \mathrm{~g}$ gula merah ke dalam ember. Kemudian difermentasi selama 15 hari sampai menghasilkan cairan dengan aroma seperti tapai.

\section{Persiapan Media Tanam dan Pengadaan Benih}

Media tanam yang digunakan dalam penelitian ini dibuat dengan mencampurkan tanah dan arang sekam dengan perbandingan 2:1. Media tersebut selanjutnya diisikan ke dalam polybag berukuran $15 \times 30 \mathrm{~cm}$, sebanyak 3/4 volume total polybag.

Adapun benih kacang hijau yang digunakan dalam budi daya ini adalah benih dalam bentuk kemasan. Benih kemasan dipilih karena benih tersebut telah bersertifikat sehingga mutunya lebih terjamin. Benih yang digunakan adalah benih kacang hijau merk panah merah.

\section{Perlakuan pada Benih dan Penanaman Benih}

Perlakuan perendaman benih atau invigorasi dilakukan sebelum benih kacang hijau ditanam. Perendaman benih diketahui dapat memperbaiki kualitas pertumbuhan tanaman. Perendaman benih dalam air kelapa dengan konsentrasi 25\% (Soekamto \& Kabelwa, 2017) selama 6 jam (Nainahas \& Taolin, 2017) diketahui memberikan hasil pertumbuhan terbaik. Oleh karena itu, taraf perendaman benih yang digunakan dalam penelitian ini adalah tanpa POC (dengan aquadest) dan dengan menggunakan POC $25 \% \mathrm{v} / \mathrm{v}$, masingmasing selama 6 jam.

Benih tersebut selanjutnya ditanam di polybag, dengan cara memberi lubang sedalam $2 \mathrm{~cm}$ di tengah media, kemudian mengisi setiap lubang dengan 1 benih tanaman kacang hijau, lalu menimbunnya kembali dengan media tanam. Budidaya tanaman ini dilakukan hingga tanaman kacang hijau berumur 67 hari setelah tanam (HST).

\section{Pengaplikasian Pupuk Organik Cair Limbah Air Kelapa dan Keong Mas pada Tanaman Kacang Hijau}

Pupuk air kelapa dan keong mas yang telah difermentasi kemudian disaring untuk memisahkan ampas dan cairan. Pupuk tersebut selanjutnya diaplikasikan pada tanaman kacang hijau yang berusia 7 hari setelah tanam (HST) dan diulang setiap 10 hari sekali. Pemupukan dilakukan hingga tanaman berumur 67 HST. Penyemprotan pupuk dilakukan pada pagi hari dan disesuaikan dengan rancangan penelitian yang telah ditentukan.

\section{Teknik Analisis Data}

Pengambilan data dilakukan pada saat tanaman berusia 17, 27, 37, 47, 57, dan 67 hari setelah tanam (HST) dengan metode observasi. Pengukuran dilakukan pada parameter tinggi tanaman, jumlah polong, bobot kering biji per tanaman, dan bobot kering akar.

Data yang diperoleh kemudian dianalisis menggunakan uji ragam ANOVA 2 arah (Lestari \& Yudhanegara, 2017). Apabila F hitung $>$ F tabel, maka dapat dilakukan uji lanjut menggunakan uji lanjut berganda Duncan (DMRT) 5\% untuk mengetahui perlakuan yang memberikan pengaruh paling signifikan. Akan tetapi, uji DMRT hanya dilakukan pada faktor pemupukan saja. Pengujian DMRT tidak dilakukan pada faktor perlakuan pada benih karena faktor tersebut hanya terdiri atas 2 taraf, sebagaimana dikemukakan oleh Susilawati (2015) bahwa syarat uji DMRT adalah dilakukan pada faktor yang memiliki lebih dari dua taraf perlakuan.

\section{HASIL DAN PEMBAHASAN}

\section{Hasil Pengamatan Tinggi Batang}

Pengukuran tinggi tanaman kacang hijau dilakukan 10 hari sekali sejak tanaman berumur 17-67 hari setelah tanam (HST). Rerata tinggi batang tercantum pada Gambar 1. Gambar tersebut menunjukkan adanya peningkatan pertumbuhan 
tinggi batang kacang hijau selama periode pengamatan akibat pemberian perlakuan. Kelompok perlakuan T2P2, yakni kelompok tanaman yang benihnya direndam oleh POC dan diberi pupuk dengan POC konsentrasi 30\% diketahui memberikan rerata tinggi batang yang terbaik dibandingkan kombinasi perlakuan lain, yakni sebesar $80.08 \mathrm{~cm}$. Data pengamatan selanjutnya dianalisis dengan menggunakan uji ANOVA 2 arah. Hasil pengujian ANOVA tercantum pada Tabel 1 .

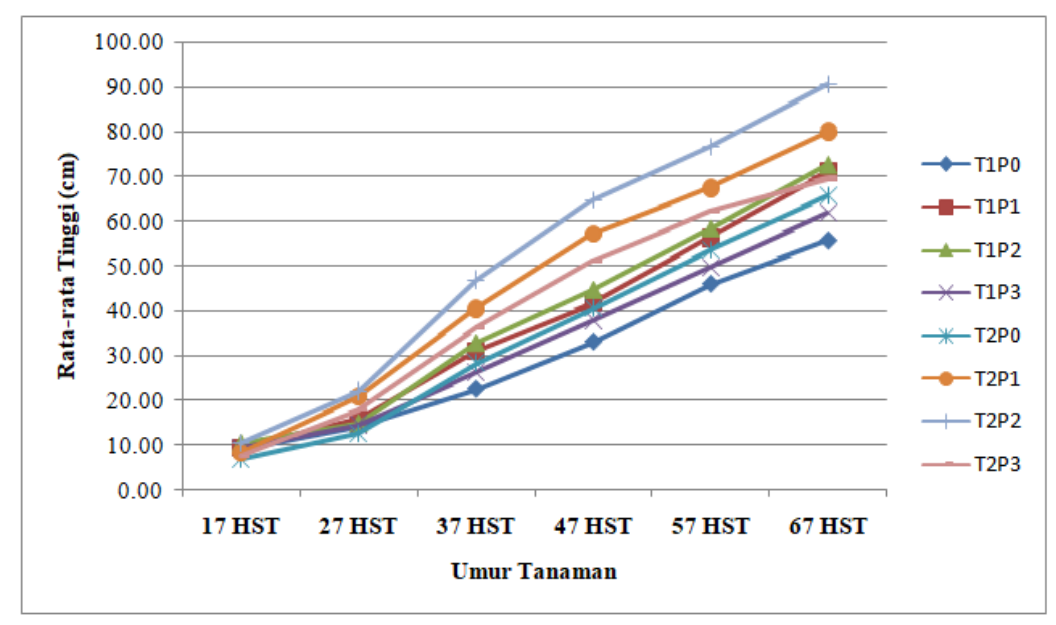

Gambar 1. Grafik rerata tinggi batang

Keterangan:

T1P0 (Perendaman tanpa POC + Pemupukan 0\%); T1P1 (Perendaman tanpa POC + Pemupukan 15\%); T1P2 (Perendaman tanpa POC + Pemupukan 30\%); T1P3 (Perendaman tanpa POC + Pemupukan 45\%); T2P0 (Perendaman dengan POC + Pemupukan 0\%); T2P1 (Perendaman dengan POC + Pemupukan 15\%); T2P2 (Perendaman dengan POC + Pemupukan 30\%); T2P3 (Perendaman dengan POC + Pemupukan $45 \%$ )

Berdasarkan Tabel 1, dapat diketahui bahwa kedua faktor yakni perlakuan pada benih $(\mathrm{T})$ memberikan pengaruh sangat nyata dengan nilai $\mathrm{F}$ hitung > F tabel $1 \%$ pada tinggi batang di seluruh waktu pengamatan, kecuali pada tinggi 17 HST. Adapun faktor pemupukan (P) memberikan pengaruh sangat nyata pada tinggi batang kacang hijau di seluruh waktu pengamatan dengan nilai $\mathrm{F}$ hitung $>\mathrm{F}$ tabel 1\%. Akan tetapi, kombinasi kedua faktor tersebut hanya memberikan pengaruh sangat nyata pada tinggi tanaman berumur 27 HST dengan nilai F hitung (4.49) > F tabel 1\% (4.31). Sedangkan, kombinasi kedua faktor berpengaruh tidak nyata pada tinggi tanaman pada waktu pengamatan lain dengan nilai $\mathrm{F}$ hitung $<\mathrm{F}$ tabel.

Berdasarkan hasil yang diperoleh, maka perlu dilakukan uji DMRT. Namun, uji DMRT hanya dilakukan pada faktor pemupukan karena syarat uji tersebut adalah dilakukan pada faktor yang memiliki lebih dari dua taraf perlakuan (Susilawati, 2015). Hasil uji DMRT ditunjukkan dalam Tabel 2. Berdasarkan tabel tersebut dapat diketahui bahwa nilai rata-rata perlakuan P2 paling tinggi dibandingkan perlakuan lain, yang berarti perlakuan tersebut memberikan pengaruh terbaik terhadap tinggi batang kacang hijau.
Tabel 1. Hasil uji ANOVA 2 arah tinggi batang

\begin{tabular}{|c|c|c|c|c|}
\hline \multirow{2}{*}{ Indikator } & \multirow{2}{*}{ SK } & \multirow{2}{*}{ F Hit } & \multicolumn{2}{|c|}{ F Tabel } \\
\hline & & & $5 \%$ & $1 \%$ \\
\hline \multirow{3}{*}{$\begin{array}{c}\text { Tinggi } 17 \\
\text { HST }\end{array}$} & Faktor T & $7.07 *$ & 4.08 & 7.31 \\
\hline & Faktor P & $4.87 * *$ & 2.84 & 4.31 \\
\hline & Faktor TxP & $0.95^{\mathrm{tn}}$ & 2.84 & 4.31 \\
\hline \multirow{3}{*}{$\begin{array}{c}\text { Tinggi } 27 \\
\text { HST }\end{array}$} & Faktor T & $18.32 * *$ & 4.08 & 7.31 \\
\hline & Faktor P & $8.17 * *$ & 2.84 & 4.31 \\
\hline & Faktor TxP & $4.49 * *$ & 2.84 & 4.31 \\
\hline \multirow{3}{*}{$\begin{array}{c}\text { Tinggi } 37 \\
\text { HST }\end{array}$} & Faktor T & $30.11 * *$ & 4.08 & 7.31 \\
\hline & Faktor P & $11.82 * *$ & 2.84 & 4.31 \\
\hline & Faktor TxP & $0.92^{\text {tn }}$ & 2.84 & 4.31 \\
\hline \multirow{3}{*}{$\begin{array}{c}\text { Tinggi } 47 \\
\text { HST }\end{array}$} & Faktor T & $40.06 * *$ & 4.08 & 7.31 \\
\hline & Faktor P & $11.70 * *$ & 2.84 & 4.31 \\
\hline & Faktor TxP & $1.42^{\mathrm{tn}}$ & 2.84 & 4.31 \\
\hline \multirow{3}{*}{$\begin{array}{c}\text { Tinggi } 57 \\
\text { HST }\end{array}$} & Faktor T & $24.79 * *$ & 4.08 & 7.31 \\
\hline & Faktor P & $9.40 * *$ & 2.84 & 4.31 \\
\hline & Faktor TxP & $0.82^{\text {tn }}$ & 2.84 & 4.31 \\
\hline \multirow{3}{*}{$\begin{array}{c}\text { Tinggi } 67 \\
\text { HST }\end{array}$} & Faktor T & $17.48 * *$ & 4.08 & 7.31 \\
\hline & Faktor P & $12.39 * *$ & 2.84 & 4.31 \\
\hline & Faktor TxP & $0.72^{\text {tn }}$ & 2.84 & 4.31 \\
\hline $\begin{array}{l}=\text { Nya } \\
=\text { Tida }\end{array}$ & hitung & $1 \%)$ & & \\
\hline
\end{tabular}


Tabel 2. Hasil uji DMRT tinggi batang

\begin{tabular}{ccccc}
\hline \multirow{2}{*}{ Indikator } & \multicolumn{4}{c}{ Faktor Pemupukan (P) } \\
& P0 & P1 & P2 & P3 \\
\hline 17 HST & $7.88 \mathrm{a}$ & $8.83 \mathrm{a}$ & $10.33 \mathrm{~b}$ & $8.42 \mathrm{a}$ \\
\hline $27 \mathrm{HST}$ & $13.25 \mathrm{a}$ & $18.33 \mathrm{~b}$ & $18.33 \mathrm{~b}$ & $16.21 \mathrm{~b}$ \\
\hline 37 HST & $25.42 \mathrm{a}$ & $35.83 \mathrm{bc}$ & $39.79 \mathrm{c}$ & $31.21 \mathrm{~b}$ \\
\hline 47 HST & $36.75 \mathrm{a}$ & $49.54 \mathrm{bc}$ & $54.75 \mathrm{c}$ & $44.63 \mathrm{~b}$ \\
\hline 57 HST & $49.83 \mathrm{a}$ & $62 \mathrm{bc}$ & $67.54 \mathrm{c}$ & $56.13 \mathrm{ab}$ \\
\hline 67 HST & $60.71 \mathrm{a}$ & $75.5 \mathrm{~b}$ & $81.5 \mathrm{~b}$ & $65.63 \mathrm{a}$ \\
\hline
\end{tabular}

Ket: angka yang diikuti dengan huruf yang sama pada kolom yang sama adalah berbeda nyata pada taraf $5 \%$ berdasarkan uji DMRT.

Hasil tersebut relevan dengan peranan hormon dalam pertumbuhan tanaman. Sebagaimana diketahui bahwa air kelapa mengandung $5.8 \mathrm{mg} / \mathrm{L}$ sitokinin dan $0.07 \mathrm{mg} / \mathrm{L}$ auksin yang dapat meningkatkan laju pertumbuhan tunas dan akar (Renvillia et al., 2016). Zat pengatur tumbuh lain yang terkandung dalam air kelapa adalah giberelin. Amarnath et al. (2015) menyebutkan bahwa giberelin dapat memicu pembelahan dan elongasi sel, sehingga dapat memperpendek waktu imbibisi dan menyebabkan waktu perkecambahan menjadi lebih cepat.

Faktor lain yang berpengaruh adalah pemenuhan unsur hara. Kalsium adalah unsur yang berperan sangat dominan pada titik tumbuh tanaman (Thor, 2019). Unsur lain yang diketahui dapat merangsang pertumbuhan vegetatif tanaman adalah fosfor (Kim \& Li, 2016; Ajmera et al., 2019). Kedua unsur ini terkandung dalam keong mas (Nurjannah et al., 2018).

Akan tetapi, pertambahan konsentrasi POC tidak mutlak berbanding lurus dengan peningkatan tinggi. Hal ini ditunjukkan oleh kelompok yang diberi POC $45 \%$ yang tidak memberikan hasil tinggi batang terbaik. Hal tersebut ditunjukkan oleh rerata nilai DMRT perlakuan P3 yang lebih kecil dari rerata nilai DMRT perlakuan P2, sebagaimana tercantum dalam Tabel 2. Kondisi ini dipengaruhi oleh keong mas yang mengandung $\mathrm{Ca}$ mencapai 40\% (Aryanti et al., 2017). Asupan Ca yang berlebihan dapat mengganggu pertumbuhan karena dapat menaikkan $\mathrm{pH}$ dan menyebabkan kekerdilan (Tangkeallo, 2019).

\section{Hasil Pengamatan Jumlah Polong}

Perhitungan jumlah polong dimulai setelah tanaman memasuki usia 47, 57, dan 67 hari setelah tanam (HST). Jumlah rata-rata polong kacang hijau tercantum dalam Gambar 2. Gambar tersebut menunjukkan bahwa kelompok T2P2 memberikan rerata jumlah polong tertinggi, yakni sebesar 48.67 buah. Data kemudian dianalisis menggunakan uji ANOVA 2 arah. Hasil pengujian tercantum dalam Tabel 3.

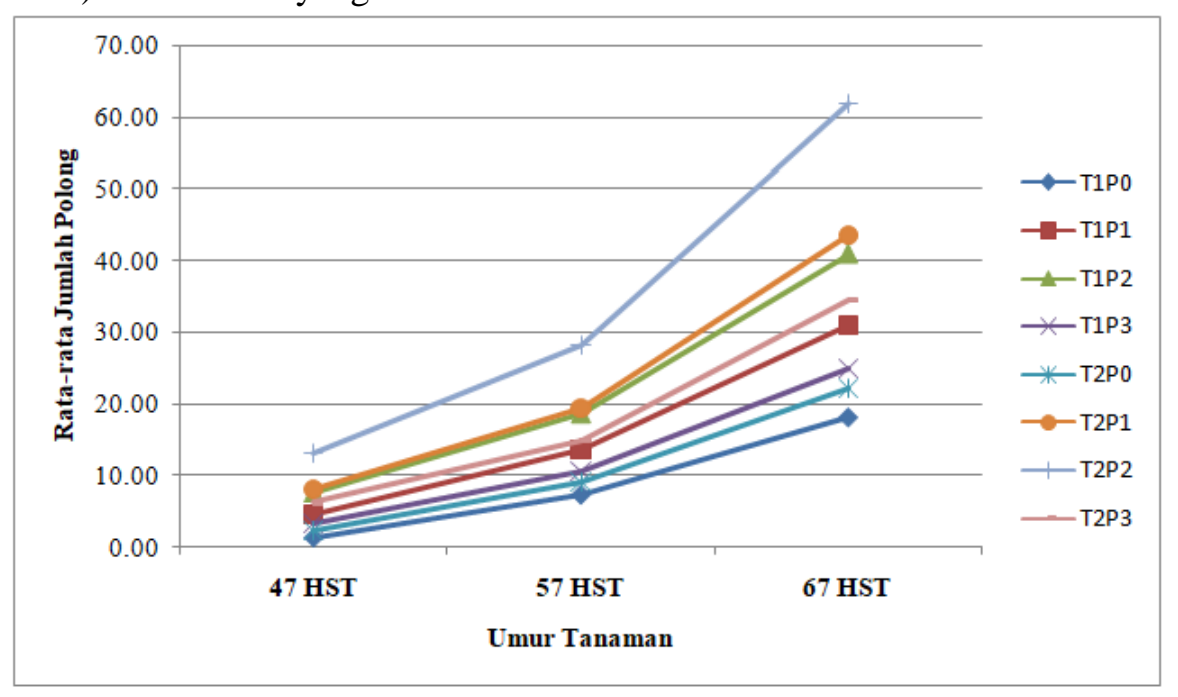

Gambar 2. Grafik rerata jumlah polong

Berdasarkan Tabel 3, diketahui bahwa kedua faktor perlakuan secara terpisah memberikan pengaruh sangat nyata terhadap jumlah polong kacang hijau dengan nilai $\mathrm{F}$ hitung $>\mathrm{F}$ tabel. Akan tetapi, kombinasi kedua faktor tersebut memberikan pengaruh tidak nyata pada jumlah polong kacang hijau dengan nilai $\mathrm{F}$ hitung $<\mathrm{F}$ tabel.
Berdasarkan hasil yang didapatkan, maka perlu dilakukan uji DMRT 5\%. Akan tetapi, pengujian lanjut DMRT hanya dilakukan pada faktor pemupukan karena prasyarat uji tersebut adalah dilakukan pada faktor yang memiliki lebih dari dua taraf perlakuan (Susilawati, 2015). Adapun hasil uji DMRT ditunjukkan dalam Tabel 4. Berdasarkan tabel tersebut dapat diketahui bahwa 
nilai rata-rata perlakuan $\mathrm{P} 2$ paling berbeda nyata dibandingkan perlakuan lain, artinya perlakuan tersebut memberikan pengaruh terbaik pada indikator jumlah polong kacang hijau.

Tabel 3. Hasil uji ANOVA 2 arah jumlah polong

\begin{tabular}{ccccc}
\hline \multirow{2}{*}{ Indikator } & \multirow{2}{*}{ SK } & \multirow{2}{*}{ F Hit } & \multicolumn{2}{c}{ F Tabel } \\
& & $\mathbf{5 \%}$ & $\mathbf{1 \%}$ \\
\hline Jumlah & Faktor T & $14.26^{* *}$ & 4.08 & 7.31 \\
\cline { 2 - 5 } Polong 47 & Faktor P & $17.71^{* *}$ & 2.84 & 4.31 \\
\cline { 2 - 5 } HST & Faktor TxP & $1.20^{\text {tn }}$ & 2.84 & 4.31 \\
\hline Jumlah & Faktor T & $11.96^{* *}$ & 4.08 & 7.31 \\
\cline { 2 - 5 } Polong 57 & Faktor P & $16.99^{* *}$ & 2.84 & 4.31 \\
\cline { 2 - 5 } HST & Faktor TxP & $1.10^{\text {tn }}$ & 2.84 & 4.31 \\
\hline Jumlah & Faktor T & $13.19^{* *}$ & 4.08 & 7.31 \\
\cline { 2 - 5 } Polong 67 & Faktor P & $16.44^{* *}$ & 2.84 & 4.31 \\
HST & Faktor TxP & $1.20^{\text {tn }}$ & 2.84 & 4.31 \\
\hline
\end{tabular}

Berdasarkan hasil tersebut, maka dapat diketahui bahwa pemupukan dengan POC membantu meningkatkan pertumbuhan, karena efisiensi penyerapan $\mathrm{N}$ menjadi lebih tinggi dengan metode pemupukan melalui daun (Riar et al., 2020). Hoque et al. (2016) mengemukakan bahwa nitrogen dan boron dapat mengurangi tingkat absisi bunga kacang hijau, sehingga dapat meningkatkan efisiensi pembentukan polong. Unsur lain yang mempengaruhi pembentukan polong adalah fosfor. Unsur P berperan penting dalam pertumbuhan fase generatif tanaman (Meylia \& Koesriharti, 2018).
Tabel 4. Hasil uji DMRT jumlah polong

\begin{tabular}{ccccc}
\hline \multirow{2}{*}{ Indikator } & \multicolumn{4}{c}{ Faktor Pemupukan (P) } \\
\cline { 2 - 5 } & P0 & P1 & P2 & P3 \\
\hline $47 \mathrm{HST}$ & $36.75 \mathrm{a}$ & $49.54 \mathrm{bc}$ & $54.75 \mathrm{c}$ & $44.63 \mathrm{~b}$ \\
\hline $57 \mathrm{HST}$ & $49.83 \mathrm{a}$ & $62 \mathrm{bc}$ & $67.54 \mathrm{c}$ & $56.13 \mathrm{ab}$ \\
\hline $67 \mathrm{HST}$ & $60.71 \mathrm{a}$ & $75.5 \mathrm{~b}$ & $81.5 \mathrm{~b}$ & $65.63 \mathrm{a}$ \\
\hline
\end{tabular}

Ket: angka yang diikuti dengan huruf yang sama pada kolom yang sama adalah berbeda nyata pada taraf $5 \%$ berdasarkan uji DMRT

Akan tetapi, pemupukan dengan POC $45 \%$ (P3) tidak memberikan jumlah polong terbaik. Hal ini ditunjukkan oleh rerata nilai DMRT perlakuan P3 yang lebih kecil dari rerata nilai DMRT perlakuan P2 pada Tabel 4. Hasil tersebut berkaitan dengan asupan $\mathrm{P}$ dan $\mathrm{Ca}$ yang berlebihan dapat menurunkan akumulasi $\mathrm{N}$ di pucuk dan daun yang menyebabkan formasi polong terhambat (Batista $e t$ al., 2018). Maka, dapat dipahami bahwa pemupukan dengan $30 \%$ POC dapat memenuhi kecukupan unsur $\mathrm{P}$ dan $\mathrm{Ca}$, sehingga pembentukan polong menjadi optimal.

\section{Hasil Pengamatan Bobot Kering Biji per tanaman}

Pengukuran bobot kering biji dilakukan di akhir penelitian, setelah tanaman dipanen pada 67 hari setelah tanam (HST). Hal ini sesuai dengan Idris (2019) yang menyebutkan bahwa kacang hijau dapat dipanen antara 65-80 HST. Hasil pengukuran tercantum dalam Gambar 3.

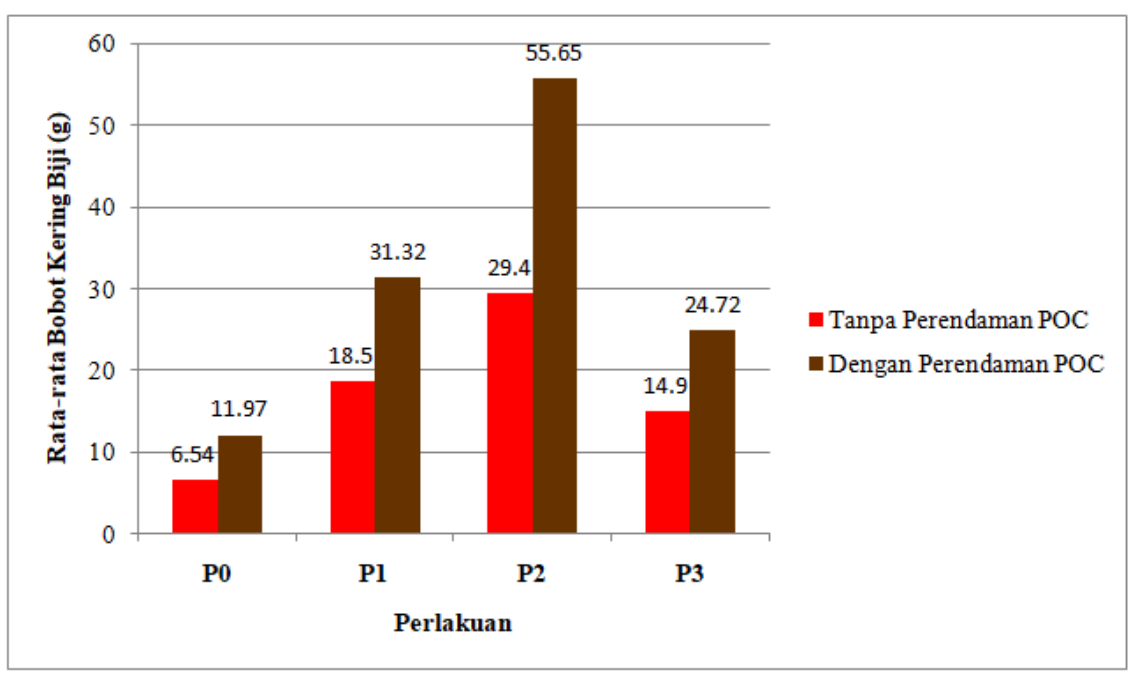

Gambar 3. Grafik rerata bobot kering biji

Berdasarkan gambar tersebut, maka dapat diketahui bahwa kelompok T2P2 memberikan bobot kering biji terbaik dibandingkan perlakuan lain dengan rata-rata sebesar 55.65 g. Data penelitian selanjutnya diolah menggunakan uji
ANOVA 2 arah. Hasil pengujian ditunjukkan dalam Tabel 5.

Tabel 5 menunjukkan bahwa kedua faktor perlakuan memberikan pengaruh positif baik secara terpisah maupun dalam bentuk kombinasi. 
Secara spesifik, diketahui bahwa faktor perlakuan pada benih berpengaruh sangat nyata terhadap bobot kering biji kacang hijau dengan nilai $\mathrm{F}$ hitung (32.03) > F tabel 1\% (7.31). Faktor lain, yakni pemupukan juga memberikan pengaruh sangat nyata dengan nilai $\mathrm{F}$ hitung (33.52) $>\mathrm{F}$ tabel $1 \%$ (7.31). Adapun kombinasi kedua faktor tersebut memberikan pengaruh nyata pada bobot kering biji dengan F hitung (3.50) > F tabel 5\% (2.84).

Tabel 5. Hasil uji ANOVA 2 arah bobot kering biji

\begin{tabular}{ccccc}
\hline \multirow{2}{*}{ Indikator } & \multirow{2}{*}{ SK } & \multirow{2}{*}{ F Hit } & \multicolumn{2}{c}{ F Tabel } \\
& & & $\mathbf{5 \%}$ & $\mathbf{1 \%}$ \\
\hline \multirow{2}{*}{$\begin{array}{c}\text { Bobot } \\
\text { Kering Biji }\end{array}$} & Faktor T & $32.03^{* *}$ & 4.08 & 7.31 \\
\cline { 2 - 5 } & Faktor P & $33.52^{* * *}$ & 2.84 & 4.31 \\
\cline { 2 - 5 } & Faktor TxP & $3.50^{*}$ & 2.84 & 4.31 \\
\hline
\end{tabular}

Hasil tersebut menjadikan perlunya dilakukan uji lanjutan DMRT. Namun, uji DMRT hanya dilakukan pada faktor pemupukan karena prasyarat uji ini adalah dilakukan pada faktor yang memiliki lebih dari dua taraf perlakuan (Susilawati, 2015). Hasil uji DMRT ditunjukkan dalam Tabel 6. Berdasarkan tabel tersebut dapat diketahui bahwa nilai rata-rata perlakuan P2 paling besar dibandingkan perlakuan lain, yang berarti perlakuan tersebut memberikan pengaruh terbaik pada indikator bobot kering biji kacang hijau.

Berdasarkan Tabel 6, maka dapat dipahami bahwa pemupukan dengan POC memberikan pengaruh positif terhadap indikator bobot kering biji. Hal ini berkaitan dengan nutrisi yang terkandung dalam POC berbahan air kelapa dan keong mas. Keong mas dikenal sebagai sumber nitrogen potensial karena mengandung protein sebesar 54-62\% (Visca \& Palla, 2018; Pertiwi \&
Saputri, 2020). Chen et al. (2013) menyimpulkan bahwa pemberian nitrogen dapat meningkatkan bobot kering biji kacang hijau. Selain itu, daging keong mas mengandung fosfor $0.2 \%$ (Delvita et al., 2015). Rasmani et al. (2020) menyebutkan bahwa fosfor berperan penting dalam pertumbuhan fase generatif tanaman, yang dimulai dengan terbentuknya primordial bunga hingga buah masak, serta akumulasi fosfor dalam biji penting dalam proses pematangan buah.

Tabel 6. Hasil uji DMRT bobot kering biji

\begin{tabular}{ccccc}
\hline \multirow{2}{*}{ Indikator } & \multicolumn{4}{c}{ Faktor Pemupukan (P) } \\
\cline { 2 - 5 } & P0 & P1 & P2 & P3 \\
\hline $\begin{array}{c}\text { Bobot } \\
\text { Kering Biji }\end{array}$ & $9.26 \mathrm{a}$ & $24.91 \mathrm{~b}$ & $42.53 \mathrm{c}$ & $19.81 \mathrm{~b}$ \\
\hline
\end{tabular}

Ket: angka yang diikuti dengan huruf yang sama pada kolom yang sama adalah berbeda nyata pada taraf 5\% berdasarkan uji DMRT

Akan tetapi, peningkatan konsentrasi POC air kelapa dan keong mas ini tidak berbanding lurus dengan pertambahan bobot kering biji kacang hijau. Sebagaimana diketahui bahwa ketersediaan $\mathrm{Ca}$ di atas normal dapat menghambat asimilasi ion lain, seperti magnesium dan kalium yang berakibat penurunan produktivitas tanaman (Giel \& Bojarczuk, 2011). Sehingga, dapat dipahami bahwa POC $30 \%$ adalah perlakuan yang dapat menyumbang kebutuhan mineral tanaman kacang hijau dengan seimbang.

\section{Hasil Pengamatan Bobot Kering Akar}

Bobot kering akar adalah komponen integral pertumbuhan tanaman (Fageria et al., 2011). Hasil rerata pengukuran bobot kering akar ditunjukkan dalam Gambar 4.

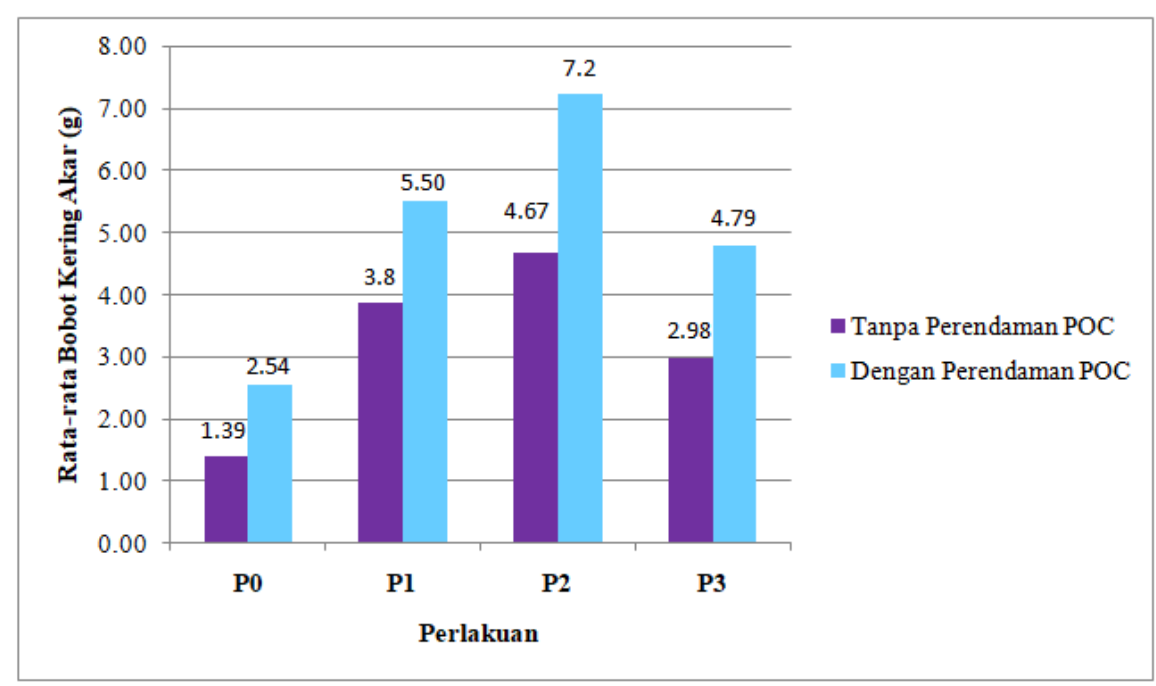

Gambar 4. Grafik rerata bobot kering akar 
Menurut Gambar 4, dapat dipahami bahwa kelompok T2P2 menghasilkan rerata bobot kering akar terbaik, yakni sebesar 7.2 g. Data tersebut kemudian dianalisis dengan uji ANOVA 2 arah. Hasil pengujian tercantum dalam Tabel 7.

Tabel 7. Hasil uji ANOVA 2 arah bobot kering akar

\begin{tabular}{ccccc}
\hline \multirow{2}{*}{ Indikator } & \multirow{2}{*}{ SK } & \multirow{2}{*}{ F Hit } & \multicolumn{2}{c}{ F Tabel } \\
& & & $\mathbf{5 \%}$ & $\mathbf{1 \%}$ \\
\hline Bobot & Faktor T & $34.23 * *$ & 4.08 & 7.31 \\
\cline { 2 - 5 } Kering & Faktor P & $29.74 * *$ & 2.84 & 4.31 \\
\cline { 2 - 5 } Akar & Faktor TxP & $0.89^{\text {th }}$ & 2.84 & 4.31 \\
\hline
\end{tabular}

Berdasarkan Tabel 7, dapat diketahui bahwa kedua faktor perlakuan secara terpisah memberikan pengaruh sangat nyata terhadap bobot kering akar kacang hijau. Hal tersebut ditunjukkan oleh faktor perlakuan pada benih yang membeikan nilai $\mathrm{F}$ hitung (34.23) > F tabel 1\% (7.31) dan faktor pemupukan yang memberikan nilai $\mathrm{F}$ hitung (29.74) > F tabel 1\% (7.31). Adapun kombinasi kedua faktor tersebut tidak memberikan pengaruh nyata dengan nilai F hitung $(0.89)<\mathrm{F}$ tabel.

Hasil tersebut menunjukkan perlunya dilakukan uji lanjutan DMRT. Akan tetapi, uji DMRT hanya dilakukan pada faktor pemupukan karena prasyarat uji tersebut adalah dilakukan pada faktor yang memiliki lebih dari dua taraf perlakuan (Susilawati, 2015). Adapun hasil uji DMRT ditunjukkan dalam Tabel 8. Berdasarkan tabel tersebut dapat diketahui bahwa nilai rata-rata perlakuan $\mathrm{P} 2$ paling berbeda nyata dibandingkan perlakuan lain, artinya perlakuan tersebut memberikan pengaruh terbaik pada indikator bobot kering akar.

Berdasarkan Tabel 8, maka dapat dipahami bahwa perbedaan konsentrasi POC memberikan pengaruh positif terhadap pertambahan bobot kering akar. Artinya, nutrisi yang terkandung dalam konsentrasi tersebut dapat mencukupi kebutuhan hara tanaman kacang hijau. Sebagaimana diketahui bahwa perkembangan akar dipengaruhi oleh ketersediaan zat hara makro dan mikro (Hambali et al., 2018). Saleh dan Pangli (2017) menyebutkan bahwa kalsium berperan penting pada titik tumbuh akar. Sedangkan, fosfor diketahui dapat meningkatkan bobot akar (Omran et al., 2020). Selain kedua nutrisi makro tersebut, beberapa mikronutrisi juga memberikan pengaruh yang signifikan terhadap perakaran tanaman kacang hijau. Unsur Zn, Fe, dan Mo dilaporkan dapat meningkatkan nodulasi dan jumlah nodul pada akar (Jamal et al., 2018). Faktor lain yang mempengaruhi proses formasi dan berkembangnya akar adalah fitohormon (Boivin et al., 2016). Sun et al. (2016) melaporkan bahwa fitohormon, yakni auksin dan etilen berperan dalam pengaturan pertumbuhan dan modifikasi akar. Peningkatan pembentukan akar menyebabkan pertambahan volume akar.

Tabel 8. Hasil uji DMRT bobot kering akar

\begin{tabular}{ccccc}
\hline \multirow{2}{*}{ Indikator } & \multicolumn{4}{c}{ Faktor Pemupukan (P) } \\
\cline { 2 - 5 } & P0 & P1 & P2 & P3 \\
\hline $\begin{array}{c}\text { Bobot Kering } \\
\text { Akar }\end{array}$ & $1.96 \mathrm{a}$ & $4.67 \mathrm{~b}$ & $5.95 \mathrm{c}$ & $3.88 \mathrm{~b}$ \\
\hline Ket:
\end{tabular}

Ket: angka yang diikuti dengan huruf yang sama pada kolom yang sama adalah berbeda nyata pada taraf $5 \%$ berdasarkan uji DMRT

Aplikasi pupuk dengan nutrisi berimbang adalah kunci untuk memperoleh hasil optimal (Mahajan \& Gupta, 2009). Pemenuhan nutrisi yang tepat dapat meningkatkan efisiensi proses di dalam tubuh tanaman, karena asimilasi zat hara dapat berlangsung dengan baik (Panhwar et al., 2018), serta dapat memperbaiki interaksi fungi dan mikroba alami di sekitar akar (Fabiańska et al., 2019). Hal ini relevan dengan hasil penelitian yang menunjukkan hasil rerata bobot akar tanaman yang diberi POC $30 \%$ lebih baik dibandingkan kelompok yang dipupuk dengan POC $45 \%$.

\section{KESIMPULAN}

Pemberian POC air kelapa dan keong mas memberikan respons positif terhadap peningkatan pertumbuhan tanaman kacang hijau (Vigna radiata). Faktor perlakuan pada benih (T) dan faktor pemupukan (P) diketahui memberikan pengaruh sangat nyata pada indikator tingi batang, jumlah polong, bobot kering biji per tanaman, dan bobot kering akar pada 17-67 hari setelah tanam (HST). Namun, faktor $\mathrm{T}$ hanya memberikan pengaruh nyata pada tinggi batang umur 17 HST. Akan tetapi, kombinasi kedua faktor hanya memberikan pengaruh sangat nyata pada tinggi batang 17 HST dan nyata pada bobot kering biji, namun tidak berpengaruh nyata pada indikator lainnya. Uji lanjutan menunjukkan bahwa pemupukan dengan 30\% POC memberikan hasil terbaik. Secara spesifik, diketahui bahwa kelompok T2P2 memberikan hasil pertumbuhan paling baik, dengan rerata tinggi $80.08 \mathrm{~cm}$, jumlah polong 48.67 buah, bobot kering biji $55.65 \mathrm{~g}$, dan bobot kering akar 7.2 g. Hal yang perlu diperhatikan adalah bahwa kualitas POC bergantung pada bahan bakunya, serta pertambahan konsentrasi POC tidak mutlak berbanding lurus dengan peningkatan 
pengaruhnya. Hal ini karena tanaman memerlukan nutrisi yang seimbang untuk dapat tumbuh dengan optimal.

\section{DAFTAR PUSTAKA}

Ajmera, I., Hodgman, T. C, \& Lu, C. (2019). An integrative systems perspective on plant phosphate research. Genes, 10(2), 1-25. https://doi.org/10.3390/genes10020139.

Amarnath, B. H., Chaurasia, A. K., Kumar, A., Chaurasia, N., Vivekanad, V., \& Singh, A. K. (2015). Effect of priming with botanicals and animal waste on germination and seedling vigour in sorghum (Sorghum bicolor L.) seeds. Pelagia Research Library: Advances in Applied Science Research, 6(10), 73-77.

Aryanti, D., Adiwirman, \& Tabrani, G. (2017). Respon kacang hijau (Phaseolus radiatus L.) terhadap ekstrak rebung bambu betung (Dendrocalamus asper Backer.) dengan pupuk hijau tithonia (Tithonia diversifolia (Hemsley) A. Gray). Jurnal Online Mahasiswa Fakultas Pertanian, 32(6), 514-520.

Azhari, R., Soverda, N., \& Alia, Y. (2018). Pengaruh pupuk kompos ampas tebu terhadap pertumbuhan dan hasil kacang hijau. Jurnal Agroecotania: Publikasi Nasional Ilmu Budidaya Pertanian, 1(2), 49-57. https://doi.org/10.22437/agroecotania.v1i2.634 1 .

Batista, K., Gerdes, L., Giacomini, A. A., de Mattos, W. T., \& Otsuk, I. P. (2018). The influence of phosphorus and calcium application rates on the mineral composition of the perennial legume Macrotyloma axillare. African Journal of Range and Forage Science, 36(1), 41-48. https://doi.org/https://doi.org/10.2989/1022011 9.2018.1523809.

Boivin, S., Fonouni-Farde, C., \& Frugier, F. (2016). How auxin and cytokinin phytohormones modulate root microbe interactions. Frontiers in Plant Science, 7(AUG2016), 1-12. https://doi.org/10.3389/fpls.2016.01240.

BPTP. (2011). Pembuatan pupuk organik menggunakan MOL. http://kalteng.litbang.pertanian.go.id/ind/index. php/publikasi-mainmenu-47-47/teknologi/187pembuatan-pupuk-organik-menggunakan-mol. Diakses tanggal 9 Juni 2021.

Chen, J. S., Zhu, R. F., \& Zhang, Y. X. (2013). The effect of nitrogen addition on seed yield and yield components of Leymus chinensis in Songnen Plain, China. Journal of Soil Science and Plant Nutrition, 13(2), 329-339. https://doi.org/10.4067/S071895162013005000027.

Delvita, H., Djamas, D., \& Ramli. (2015). Pengaruh variasi temperatur kalsinasi terhadap karakteristik kalsium karbonat (CaCO3) dalam cangkang keong sawah (Pila ampullacea) yang terdapat di Kabupaten Pasaman. Pillar of Physics, 6(2015), 17-24. https://doi.org/10.24036/1933171074.

Dharmawati, S., Widaningsih, N., \& Firahmi, N. (2016). Biologi keong rawa (Pomacea glauca dan Pomacea canaliculata) di perairan rawa Kalimatan Selatan. Media Sains, 9(1), 105-109.

Direktorat Jenderal Tanaman Pangan. (2020). Laporan tahunan Direktorat Jenderal Tanaman Pangan tahun 2019. Kementrian Pertanian: Jakarta.

Fabiańska, I., Sosa-Lopez, E., \& Bucher, M. (2019). The role of nutrient balance in shaping plant root-fungal interactions: facts and speculation. In Current opinion in microbiology (Vol. 49, pp. 90-96). Elsevier Ltd. https://doi.org/10.1016/j.mib.2019.10.004.

Fageria, N. K., Moreira, A., \& Coelho, A. M. (2011). Yield and yield components of upland rice as influenced by nitrogen sources. Journal of Plant Nutrition, 34(3), 361-370. https://doi.org/10.1080/01904167.2011.536878

Giel, P., \& Bojarczuk, K. (2011). Effects of high concentrations of calcium salts in the substrate and its $\mathrm{pH}$ on the growth of selected rhododendron cultivars. Acta Societatis Botanicorum Poloniae, 80(2), 105-114. https://doi.org/10.5586/asbp.2011.021.

Gitadevarsa, T., Handayani, S., \& Warnaen, A. (2019). Rancangan penyuluhan tentang proses pembuatan pupuk organik cair dari urine sapi potong menggunakan mikroorganisme lokal (MOL) bongkol pisang di Desa Wonorejo Kecamatan Lawang Kabupaten Malang. Jurnal Penyuluhan Pembangunan, 1(1), 44-52. https://doi.org/10.34145/jppm.v1i1.14.

Hambali, P. F., Murdiono, W. E., \& Koesriharti. (2018). Pengaruh substansi AB Mix dengan pupuk organik cair kelinci pada pertumbuhan dan hasil tanaman selada merah (Lactuca sativa L.) dengan sistem rakit apung. Jurnal Produksi Tanaman, 6(12), 3096-3105.

Harahap, F. (2014). The growth of orchid (Dendrobium sp.) in in vitro giving with coconut water on different medium. 
Proceeding: The First International Seminar on Trends in Science and Science Education 2014 State University of Medan, 46-53.

Hartatik, W., Husnain, \& Widowati, L. R. (2015). Peranan pupuk organik dalam peningkatan produktivitas tanah dan tanaman. Jurnal Sumberdaya Lahan, 9(2), 107-120. https://doi.org/10.21082/jsdl.v9n2.2015.\%25p.

Hoque, A., Hassan, M., Khan, M., Khatun, R., \& Baten, M. (2016). Effect of temperature on flower and pod abscission and yield of three soybean genotypes. Journal of Environmental Science and Natural Resources, 8(2), 89-92. https://doi.org/10.3329/jesnr.v8i2.26872.

Idris, R. (2019, November 29). Budidaya kacang hijau.

http://cybex.pertanian.go.id/mobile/artikel/847 05/Budidaya-Kacang-Hijau/. Diakses tanggal 15 Juni 2021.

Jamal, A., Khan, M. I., Tariq, M., \& Fawad, M. (2018). Response of mung bean crop to different levels of applied iron and zinc. Journal of Horticulture and Plant Research, 3, 13-22. https://doi.org/10.18052/www.scipress.com/jh pr.3.13.

Jiao, K., Li, X., Su, S., Guo, W., Guo, Y., Guan, Y., Hu, Z., Shen, Z., \& Luo, D. (2019). Genetic control of compound leaf development in the mungbean (Vigna radiata L.). Horticulture Research, 6(1), 1-12. https://doi.org/10.1038/s41438-018-0088-0.

Kim, H. J., \& Li, X. (2016). Effects of phosphorus on shoot and root growth, partitioning, and phosphorus utilization efficiency in Lantana. HortScience, 51(8), 1001-1009. https://doi.org/10.21273/hortsci.51.8.1001.

Komalasari, W. B. (2018). Statistik konsumsi pangan 2018. Jakarta: Kementrian Pertanian.

Lestari, E. K., \& Yudhanegara, M. R. (2017). Penelitian pendidikan matematika. Bandung: PT. Refika Aditama.

Liunokas, A. B., Bana, J. J., \& Amalo, D. (2019). Pengaruh pemberian ekstrak pinang (Areca catechu L.) terhadap kesintasan telur keong mas (Pomacea canaliculata Lamarck). Jurnal $\begin{array}{llll}\text { Biologi } & \text { Tropis, } & \text { 19(2), } & 294 .\end{array}$ https://doi.org/10.29303/jbt.v19i2.1302.

Mahajan, A., \& Gupta, R. D. (2009). Balanced Use of Plant Nutrients. In Integrated nutrient management (INM) in a sustainable ricewheat cropping system (pp. 119-125). Springer. https://doi.org/10.1007/978-1-4020-9875-8_8.

Manurung, D. E. B., Heddy, Y. S., \& Hariyono, D. (2017). Pengaruh pemberian air kelapa pada beberapa batang atas terhadap pertumbuhan bibit karet (Hevea brasiliensis Muell Arg.) hasil okulasi. Jurnal Produksi Tanaman, 5(4), 686 694.

Meylia, R. D., \& Koesriharti. (2018). Pengaruh pemberian pupuk fosfor dan sumber kalium yang berbeda terhadap pertumbuhan dan hasil tanaman tomat (Lycopersicon esculentum Mill.). Jurnal Produksi Tanaman, 6(8), 19341941.

Nainahas, K. I., \& Taolin, R. I. C. O. (2017). Pengaruh lama perendaman air kelapa dan frekuensi penyemprotan urin sapi terhadap pertumbuhan bibit pinang (Areca catechu L.). Savana Cendana: Jurnal Pertanian Konservasi Lahan Kering, 2(01), 8-10. https://doi.org/10.32938/sc.v2i01.78.

Nurjannah, N., Yanto, S., \& Patang, P. (2018). Pemanfaatan keong mas (Pomacea canaliculata L.) dan limbah cangkang rajungan (Portunus pelagicus) menjadi pakan ternak untuk meningkatkan produksi telur itik. Jurnal Pendidikan Teknologi Pertanian, 3(2017), 137147. https://doi.org/10.26858/jptp.v3i2.5525.

Omran, A. H., Dass, A., Rajanna, G. A., Dhar, S., Choudhary, A. K., Meena, S. L., \& Rathore, S. S. (2020). Root-shoot characteristics, yield and economics of mungbean (Vigna radiata L.) under variable rates of phosphorus and nitrogen. Bangladesh Journal of Botany, 49(1), 13-19. https://doi.org/10.3329/bjb.v49i1.49086.

Pambudi, N. D. (2011). Pengaruh metode pengolahan terhadap kelarutan mineral keong mas (Pomacea canaliculata) dari Perairan Situ Gede, Bogor. (Skripsi). Institut Pertanian Bogor, Bogor.

Panhwar, Q. A., Ali, A., Naher, U. A., \& Memon, M. Y. (2018). Fertilizer management strategies for enhancing nutrient use efficiency and sustainable wheat production. In Organic farming: Global perspectives and methods (pp. 17-39). Elsevier. https://doi.org/10.1016/B9780-12-813272-2.00002-1.

Pertiwi, M. P., \& Saputri, D. D. (2020). Golden apple snail (Pomacea canaliculata) as an alternative protein source in Pasupati catfish (Pangasius sp.) fish feed. Nusantara Bioscience, 12(2), 162-167. https://doi.org/10.13057/nusbiosci/n120212.

Prades, A., Dornier, M., Diop, N., \& Pain, J. P. (2012). Coconut water uses, composition and properties: A review. Fruits, 67(2), 87-107. https://doi.org/10.1051/fruits/2012002.

Prayitna, A. M. S. (2017). Pengaruh pemberian 
pupuk organik cair keong mas (Pomacea canaliculata) dan penggunaan mulsa hitam perak terhadap pertumbuhan dan hasil tanaman kacang hijau (Vigna radiata). (Skripsi). Universitas Sanata Dharma, Yogyakarta.

Prianti, A. L., Yusna, A., Hariati, E., \& Harahap, F. (2017). Pengaruh fitohormon alami terhadap perkecambahan dan pertumbuhan tanaman cabai rawit. In Prosiding Seminar Nasional MIPA III (pp. 318-323). Aceh, Indonesia: Fakultas Pertanian, Universitas Syah Kuala.

Putri, R. T. D., Ismah, R., Alamiah, N. E., \& Sahrir, D. C. (2019). Pemanfaatan keong mas menjadi pakan ternak untuk meningkatkan produksi telur itik. Seminar Nasional Pendidikan Sains, 86-90.

Rasmani, Aziz, S. A., \& Suketi, K. (2020). Correlations of nitrogen, phosphorus, potassium, pigments and total flavonoids of Moringa oleifera Lam. leaves in the vegetative and generative phases. Journal of Tropical Crop Science, 7(02), 75-85. https://doi.org/10.29244/jtcs.7.02.75-85.

Renvillia, R., Bintoro, A., \& Riniarti, M. (2016). Penggunaan air kelapa untuk setek batang jati (Tectona grandis). Jurnal Sylva Lestari, 4(1), 61. https://doi.org/10.23960/js11461-68.

Riar, A., Gill, G., \& McDonald, G. K. (2020). Rate of nitrogen rather than timing of application influence yield and NUE of canola in south australian mediterranean environments. Agronomy, 10(10), 7-9. https://doi.org/10.3390/agronomy10101505.

Riyanto, R., Dahlan, Z., \& Slamet, A. (2015). Studi ekologi keong mas (Pomacea canaliculata L.) sebagai bahan sumbangan materi pembelajaran kontekstual pada mata pelajaran biologi SMA di Oku Timur. Jurnal Pembelajaran Biologi, 2(1), 51-63.

Saleh, A. R., \& Pangli, M. (2017). Respon pertumbuhan dan produksi tanaman sawi hijau (Brassica juncea L.) terhadap berbagai macam media hidroponik. Jurnal AgroPet, 14(1), 9-19.

Saputra, K., Sutriyono, \& Brata, B. (2018). Populasi dan distribusi keong mas (Pomacea canaliculata L.) sebagai sumber pakan ternak pada ekosistem persawahan di Kota Bengkulu. Jurnal Sain Peternakan Indonesia, 13(2), 189201. https://doi.org/10.31186/jspi.id.13.2.189201.

Soekamto, M. H., \& Kabelwa, S. (2017). Pengaruh air kelapa terhadap perkecambahan benih kedelai (Glycine max (L) Merr. Median : Jurnal
Ilmu Ilmu Eksakta, 9(2), 9. https://doi.org/10.33506/md.v9i2.17.

Suarmustika, I. G. A., Suartini, N. M., \& Subagio, J. N. (2018). Variasi morfometri dan karakter morfologi keong mas (Pomacea canaliculata) pada sawah di Desa Abiansemal Badung-Bali. Simbiosis, 6(2), 60. https://doi.org/10.24843/jsimbiosis.2018.v06.i 02.p06.

Suhastyo, A. A., Anas, I., Andreas Santosa, D., \& Lestari, Y. (2013). Studi mikrobiologi dan sifat kimia mikroorganisme lokal (MOL) yang digunakan pada budidaya padi metode Sri (System of rice intensification). Sainteks Volume, 10(2), 29-39. https://doi.org/10.30595/ sainteks.v10i2.148.

Sun, L., Tian, J., Zhang, H., \& Liao, H. (2016). Phytohormone regulation of root growth triggered by $\mathrm{P}$ deficiency or Al toxicity. Journal of Experimental Botany, 67(12), 3655-3664. https://doi.org/10.1093/jxb/erw188.

Sun, Y. N., Qin, X. Y., Lv, Y. K., Li, S. Z., \& Wei, C. (2014). Simultaneous determination of five phytohormones in mungbean sprouts of China by micellar electrokinetic chromatography. Journal of Chromatographic Science, 52(7), 725-729. https://doi.org/10.1093/chromsci/bmt102.

Suriyadi. (2020). Pengendalian hama keong mas. http://cybex.pertanian.go.id/mobile/artikel/925 65/Pengendalian-Hama-Keong-Mas-/. Diakses tanggal 8 Juni 2021.

Susilawati, M. (2015). Bahan Ajar Perancangan Percobaan. Denpasar: Universitas Udayana.

Tangkeallo, Y. P. (2019). Pupuk kalsium, memperkuat daya tahan tanaman terhadap serangan penyakit. http://cybex.pertanian.go.id/mobile/artikel/727 10/Pupuk-Kalsium-Memperkuat-Daya-TahanTanaman-Terhadap-Serangan-Penyakit/. Diakses tanggal 27 Mei 2021.

Taufikurohman. (2018). Keong, binatang kecil yang mempunyai peran penting di alam - Ditjen Konservasi Sumber Daya Alam dan Ekosistem. http://ksdae.menlhk.go.id/berita/4393/keong,binatang-kecil-yang-memiliki-peran-pentingdi-alam.html. Diakses tanggal 9 Juni 2021.

Thor, K. (2019). Calcium-nutrient and messenger. Frontiers in Plant Science, 10(440), 1-7. https://doi.org/10.3389/fpls.2019.00440.

Visca, M. D., \& Palla, S. Q. (2018). Golden apple snail, Pomacea canaliculata meal as protein source for rabbitfish, Siganus guttatus culture. AACL Bioflux, 11(2), 533-542. 
(c) (†) (8)

This work is licensed under a Creative Commons Attribution-NonCommercial 4.0 International License 